\title{
Anti-Inflammatory Effect of Essential Oils Extracted from Wood of Four Coniferous Tree Species ${ }^{1}$
}

\author{
Jiyoon $\mathrm{YANG}^{2,3} \cdot$ Won-Sil $\mathrm{CHOI}^{4} \cdot \mathrm{Jae}^{-W o o} \mathrm{KIM}^{2} \cdot$ Sung-Suk $\mathrm{LEE}^{2} \cdot \mathrm{Mi}-\mathrm{Jin} \mathrm{PARK} \mathbb{D}^{2, \dagger}$
}

\begin{abstract}
The aim of this study was to evaluate the anti-inflammatory effects of essential oils extracted from the wood of Chamaecyparis obtusa, Pinus densiflora, Pinus koraiensis, and Larix kaempferi. Essential oils were extracted by hydrodistillation, and their chemical components were determined by GC/MS. Major chemical components of these essential oils were $\alpha$-cadinol (19.25\%), $\tau$-muurolol (14.20\%), and $\alpha$-pinene (13.74\%) in C. obtusa; $\alpha$-pinene (47.16\%), longifolene (14.31\%), $\beta$-phellandrene (11.78\%), and $\beta$-pinene (11.02\%) in P. densiflora; $\alpha$-pinene (13.49\%) and longifolene $(10.79 \%)$ in P. koraiensis, and geranyl linalool $(23.58 \%)$ and $\alpha$-pinene $(18.57 \%)$ in $L$. kaempferi. To evaluate the anti-inflammatory effects of essential oils, lipopolysaccharide (LPS)-induced RBL-2H3 mast cells were treated with these essential oils; then, the changes in the mRNA expression level of the cytokines IL-4 and IL-13 were examined. Further, degranulation was evaluated by measuring $\beta$-hexosaminidase release. After LPS-induced RBL-2H3 mast cells were exposed to $10^{-7} \%$ of all types of essential oils, the gene expression levels of IL-4 and IL-13 within the cells remarkably decreased. The relative mRNA expression level of IL-4 was $69.6 \%$ in P. densiflora, $63.2 \%$ in P. koraiensis, $55.1 \%$ in C. obtusa, and $45.8 \%$ in L. kaempferi compared with that in the group treated with LPS. The mRNA expression level of L-13 should a similar trend. The inhibitory rate of IL-13 mRNA expression of P. densiflora, P. koraiensis, C. obtusa, and L. kaempferi was $57.8 \%, 57.1 \%, 51.1 \%$, and $34.5 \%$, respectively. $\beta$-Hexosaminidase release significantly decreased following the treatment with the four types of essential oils. The rate of $\beta$-hexosaminidase release were $38.1 \%$ C. obtusa; $33.0 \%$ P. densiflora; 27.4\% P. koraiensis; and 9.1\% L. kaempferi. Among all types of essential oils, that extracted from P. densiflora wood showed the highest anti-inflammatory activity. These results show that the tested essential oils exert an anti-inflammatory effect through the inhibition of degranulation and expression of cytokines.
\end{abstract}

Keywords: Chamaecyparis obtusa, Pinus densiflora, Pinus koraiensis, Larix kaempferi, essential oil, anti-inflammatory effect

\section{INTRODUCTION}

Forests account for approximately $64 \%(6,335,000$ ha) of the national territory of Korea, of which $36.9 \%$
$(2,339,000 \mathrm{ha})$ is occupied by coniferous forest that cover a larger proportion of the land than broadleaf forest $[32.0 \%$ (2,029,000 ha)] (Kong, 2004). Based on species, coniferous forest occupies a vast amount of

\footnotetext{
${ }^{1}$ Date Received July 11, 2019, Date Accepted October 16, 2019

2 Division of Wood Chemistry, Department of Forest Products, National Institute of Forest Science, Seoul 02455, Republic of Korea

${ }^{3}$ Division of Life Sciences, School of Life Sciences, Korea University, Seoul 02841, Republic of Korea

${ }^{4}$ National Instrumentation Center for Environmental Management, Seoul National University, Seoul 08826, Republic of Korea

$\dagger$ Corresponding author: Mi-Jin PARK (e-mail: lionpmj@korea.kr, ORCID: 0000-0002-7748-3886)
} 
the land $\left[43.7 \%\left(403971300 \mathrm{~m}^{3}, 172.7 \mathrm{~m}^{3} / \mathrm{ha}\right)\right]$ (Korea Forest Service, Basic Statistics of Forests, 2016). Among coniferous trees, cypress, pine, pine nut, and Japanese larch are used for timber (Korea Forest Service, Basic Statistics of Forests, 2016). Since cypress (Chamaecyparis obtusa Sieb. et Zucc.) was first introduced from Japan in 1904, it has been planted in the southern area as an economic species, and it has continuously been cultivated by national projects to develop more green areas (Lee et al., 2014). Cypress timber is considered high-quality wood with a unique scent; thus, it is widely used in architecture and manufacture of high-end furniture. Cypress extract contains various substances, of which bioactive substances are well known. All parts of pine (Pinus densiflora Sieb. et Zucc.), an evergreen softwood species, are very useful because its leaf, conifer cone, and pine resin are widely used. Pine are also used in home remedies for the treatment of diseases such as neuralgia, diabetes, and hypertension (Cho et al., 2009). Among other local tree species, pine is particularly closely related to the local community. Indeed, it has been regarded as a vital tree species in terms of cultural value.

Pine nut ( $P$. koraiensis Sieb. et Zucc.) offers double benefits because it provides timber and edible seeds. Because of its robust tolerance to cold and resistance against damages caused by blights and harmful insects, its plantation has long been recommended by the government considering its potential as a long-term source of timber since the 1960s. Japanese larch (Larix kaempferi Lamb.) was introduced from Japan in the 1910s, it has been planted across the country, because of its rapid growth, and is used for artificial forests and is widely used in the manufacture of wooden products and architectural materials (Kang et al., 2016; Han et al., 2017). Korea's appreciation toward forests is deepening, and the demand for the use of these forests is diversifying. Pine, pine nut, and Japanese larch are the tree species that are harvested across the country on a large scale. Thus, research to enhance the use of locally accumulated resources and their byproducts following woodcutting is currently required.

With many synthetic drugs and chemical preservatives being identified to be hazardous, natural products are drawing considerable attention. Various studies have been conducted on the use of tree extracts including essential oils for the development of antioxidants (Jung et al., 2017; Kim et al., 2017), anti-inflammatory drugs (Min et al., 2017; Yang et al., 2017), antifungal agents (Rho et al., 2014; Kim et al., 2013), anticomplements (Li et al., 2018), and biofilm inhibitors (Ham and Kim, 2018). Essential oils, secondary metabolites of plants, have various biological activities, among which soothing effect and robustness are well known. In particular, essential oils are often used in aroma therapy for their known benefits to restore mental and physical balance as well as to maintain homeostasis. These properties are induced by the substances present in them such as ketone, terpene, and phenolic ether (Carvalho-Freitas and Costa, 2002). A study showed the antifungal effect of an essential oil extracted from leaves of coniferous trees such as pine, pine nut, cypress, and fir tree (Hong et al., 2004; Kim et al., 2016). Ibrahim et al. evaluated the anti-inflammatory and scar-healing effects of an essential oil extracted from the cones of six types of coniferous trees belonging to the Pinaceae family. Plants belonging to an identical family and genus showed different degrees of anti-inflammatory and scar-healing effects. Cedrus libani and Abies cilicica subsp. Cilicica have anti-inflammatory effects. Further, the herbicidal effect of essential oils extracted from the leaves of locally bred pine, pine nut, Japanese larch, and Khingan fir was studied (Yun et al., 2013). As a result of verifying the in vitro herbicidal activity of essential oils extracted from four coniferous tree species on germination, these essential oils (except that 
derived from pine leaf) showed herbicidal activity. The different degrees of herbicidal activity because of the different substances present in these essential oils and their concentrations affects cytotoxicity and the cell cycle. The importance of these tree species and their concentration in the field where they can be practically used is high (Ahn et al., 2018).

There are varied ongoing studies on the bioactivity of essential oils extracted from coniferous tree species, but limited to leaves and the studies on the bioactivity of essential oils extracted from the wood are insufficient. Therefore, this study aimed to compare and analyze the anti-inflammatory activity of essential oils extracted from the wood of four coniferous tree species including cypress (C. obtusa), pine ( $P$. densiflora), pine nut ( $P$. koraiensis), and Japanese larch (L. kaempferi), all of which are typical local tree species used for timber. This study also aimed to verify the potential use of essential oils extracted from coniferous wood for improving or preventing allergic diseases.

\section{MATERIALS and METHODS}

\subsection{Plant materials}

Cypress (C. obtusa Sieb. et Zucc.) and pine ( $P$. densiflora Sieb. et Zucc.) were purchased through the Gapeyong National Forestry Cooperative Federation, which were obtained from the South Sea in December of 2014. Japanese larche (L. kaempferi Sieb. et Zucc.) was cut in Pyeongchang in December 2015, whereas pine nut (P. koraiensis Sieb. et Zucc.) was cut in Gapyeong in January 2016.

\subsection{Essential oil extraction}

The wood of cypress, pine, pine nut, and Japanese larch were grinded to extract essential oils through hydrodistillation. One $\mathrm{kg}$ of a sample was placed in a $10 \mathrm{~L}$ round-bottomed flask; then, $6 \mathrm{~L}$ distilled water was poured and the mixture was heated to $105^{\circ} \mathrm{C}$. Vaporized substances formed an extract, which was cooled to obtain essential oils. Extraction continued until no more essential oil was obtained, which lasted for approximately $7 \mathrm{~h}$. The extracted essential oil was processed to remove moisture using anhydrous $\mathrm{Na}_{2} \mathrm{SO}_{4}$ (SAMCHUN,98.5). The final product was stored in a refrigerator until analysis.

The yield rate of essential oils was calculated using the following equation.

Yield rate $[\%(\mathrm{w} / \mathrm{w})]=$

\{weight of extracted essential oil (g)/ oven dry weight of samples $(\mathrm{g})\} \times 100 \%$

\subsection{Cell culture}

To assess the level of anti-inflammatory effect of essential oils extracted from the wood of the four coniferous tree species, RBL-2H3 mast cells (CRL$22256^{\mathrm{TM}}$; American Type Culture Collection, Manassas, Manassas, VA, USA) were purchased in lots. These cells were cultured in Dulbecco's modified Eagle's medium (Gibco) containing 10\% fetal bovine serum (Gibco), 1\% penicillin/streptomycin (Gibco), and 0.4 $\mu \mathrm{L} / \mathrm{mL}$ mycoplasma guard in an incubator (Panasonic, $\mathrm{MCO}-19 \mathrm{AIC})$ at $37^{\circ} \mathrm{C}\left(5 \% \mathrm{CO}_{2}\right)$.

\subsection{Chemical composition of essential oils}

The essential oils extracted from the wood of the four coniferous tree species were qualitatively analyzed using GC/MS (Trace 1310/ISQ-LT, ThermoScientific, USA). The Tr-5MS capillary column $(30 \mathrm{~m} \times 0.25 \mathrm{~mm}$ $\times 0.25 \mu \mathrm{m}$; ThermoScientific, USA) was used, and helium ( $1 \mathrm{~mL} / \mathrm{min}, 25 \mathrm{psi})$ was used as the carrier gas. Sample inlet was maintained at $250^{\circ} \mathrm{C}$. Further, an oven was maintained at $40^{\circ} \mathrm{C}$ for $3 \mathrm{~min}$, after which the temperature was increased by $3^{\circ} \mathrm{C}$ until it reached $200^{\circ} \mathrm{C}$ 
and then was raised by $15^{\circ} \mathrm{C}$ until it reached $340^{\circ} \mathrm{C}$ for $10 \mathrm{~min}$. FID and mass spectrum of detected chemicals were recorded. FID was maintained at $280^{\circ} \mathrm{C}$, and the flow rate for helium was $40 \mathrm{~mL} / \mathrm{min}$. The temperatures of the interface of a mass spectrometer and ion source were maintained at $280^{\circ} \mathrm{C}$ and $250^{\circ} \mathrm{C}$, respectively.

The analyzed substances in essential oils were selected based on the value showing the highest spectral matching when the $\mathrm{S} / \mathrm{N}$ ratio reached $\geq 100$ in total-ion chromatography at peaks with NIST library search program (ver.11). Furthermore, to confirm the chemical composition of essential oils, the Kovats retention index was calculated using $n$-alkanes $\left(\mathrm{C}_{8}-\mathrm{C}_{20}\right.$, Sigma-Aldrich).

\subsection{3-(4,5-Dimethylthiazole-2-yl)-2,5- diphenyl tetrazolium bromide (MTT) assay}

To assess the cytotoxicity of essential oils toward RBL-2H3 mast cells, the MTT assay was performed. A $200 \mu \mathrm{L}$ culture medium was used, and cells were seeded in a 96-well plate at a density of $8 \times 10^{3}$ cells/well. Then, the plate was incubated in an incubator at $37^{\circ} \mathrm{C}$ with $5 \% \mathrm{CO}_{2}$ for 1 day. The MTT reagent (Sigma, Cat.\#. 11465007001) was added to the cells that were exposed to the essential oils at concentrations of $10^{-7} \%-10^{-5} \%$. They were again placed in the incubator at $37^{\circ} \mathrm{C}$ for $6 \mathrm{~h}$. The growth culture medium and MTT reagent were removed, and the mixture was washed with Dulbecco's phosphate-buffered saline (Gibco). Next, $100 \mu \mathrm{L}$ dimethyl sulfoxide (Sigma) was added to each well, and the mixture was stored at room temperature for $10 \mathrm{~min}$. The optical density of the cells was determined at a wavelength of $540 \mathrm{~nm}$ using a spectrophotometer.

\subsection{Quantitative mRNA analysis by real-time PCR}

RBL-2H3 mast cells were seeded into a 6-well plate at a density of $3 \times 10^{5}$ cells $/$ well, and the plate was incubated for $24 \mathrm{~h}$ with $1 \mu \mathrm{g} / \mathrm{mL}$ lipopolysaccharide (LPS). Then, the essential oils were processed. After $24 \mathrm{~h}$ cultivation, $500 \mu \mathrm{L}$ TRIzol reagent (Invitrogen Life Technologies) was added to each well of the 6-well plate, and the cells were dissolved and moved into tubes. Next, $100 \mu \mathrm{L}$ chloroform was added, and the tubes were centrifuged at $14,000 \mathrm{rpm}$ for $10 \mathrm{~min}$. Further, $150 \mu \mathrm{L}$ of the obtained supernatant was collected, and isopropanol was added in the same amount. RNA was condensed at $-20^{\circ} \mathrm{C}$ for $24 \mathrm{~h}$. After centrifuging the mixture at $14,000 \mathrm{rpm}$ at $4^{\circ} \mathrm{C}$ for $10 \mathrm{~min}$, the supernatant was removed, $200 \mu \mathrm{L}$ DEPC/EtOH was added, the mixture was centrifuged, and then the entire supernatant was removed. Next, $20 \mu \mathrm{L}$ DEPC/DW was added, the mixture was stored at $55^{\circ} \mathrm{C}$ for $5 \mathrm{~min}$ to increase the temperature, and then RNA concentration was measured at a wavelength of $260 \mathrm{~nm}$ using a microplate spectrophotometer (Epoch, model Take 3; BioTek Inc., Winooski, VT, USA). cDNA was synthesized from mRNA using a quantitative method; then, real-time PCR was performed using a real-time PCR system (Applied Biosystems, Foster, CA, USA). The sequences of the oligonucleotide primers used are shown in Table 1. The relative values for each wood essential oil were determined using the RQ software (version 1.3, Applied Biosystems).

Table 1. Oligonucleotide sequences for quantitative real-time polymerase chain reaction

\begin{tabular}{cl}
\hline Gene & Primer sequence $\left(5^{`}-3^{`}\right)$ \\
\hline \hline IL-4 & $\mathrm{F}:$ tgatgtacctccgtgcttga \\
& $\mathrm{R}:$ aggacatggaagtgcaggac \\
& $\mathrm{F}:$ ctggaatccetgaccaacat \\
IL-13 & $\mathrm{R}:$ ccatagcggaaagttgctt \\
& $\mathrm{F}:$ ttctacaatgagctgcgtgtg \\
$\beta$-actin & $\mathrm{R}:$ accagaggcatacagggaca \\
\hline
\end{tabular}

F: forward, R: reverse 
Jiyoon YANG $\cdot$ Won-Sil CHOI $\cdot$ Jae-Woo KIM $\cdot$ Sung-Suk LEE $\cdot$ Mi-Jin PARK

\section{7. $\beta$-Hexosaminidase secretion assay}

To analyze the changes in the rate of $\beta$-hexosaminidase release by the essential oils in LPS-induced RBL-2H3 mast cells, cells were seeded into a 96-well plate at a density of $8 \times 10^{3}$ cells/well and then stimulated with DNP-specific IgE (800 ng/mL, Sigma, USA). After removing the culture medium, the mixture was washed twice with Tyrodes' solution [119 $\mathrm{mM} \mathrm{NaCl}, 4.74 \mathrm{mM} \mathrm{KCl}, 2.5 \mathrm{mM} \mathrm{CaCl} 2,1.19 \mathrm{mM}$ $\mathrm{MgSO}_{4}, 10 \mathrm{mM}$ HEPES, $5 \mathrm{mM}$ glucose, $0.1 \%(\mathrm{w} / \mathrm{v})$ $\mathrm{BSA} ; \mathrm{pH}$ 7.3] and cultivated for $15 \mathrm{~min}$; a mixture of the essential oils and DNP/BSA was incubated for $1 \mathrm{~h}$. Then, $50 \mu \mathrm{L}$ supernatant was transferred to a tube, added with $200 \mu \mathrm{L}$ of $1 \mathrm{mM}$ P-nitrophenyl-Nacetyl $\beta$-D-glucosaminide, and cultured at $37^{\circ} \mathrm{C}$ for $1 \mathrm{~h}$. To terminate the reaction, $0.05 \mathrm{M}$ sodium bicarbonate buffer was added, and optical density was measured at a wavelength of $405 \mathrm{~nm}$.

\section{RESULTS and DISCUSSION}

\subsection{Yield and chemical composition of essential oils}

The yield rate of the essential oils extracted from the wood of the four coniferous tree species was the highest for cypress $(0.86 \%)$ and pine $(0.75 \%)$ followed by pine nut $(0.25 \%)$ and Japanese larch $(0.06 \%)$.

The chemical composition of these essential oils is summarized in Table 2. In brief, the essential oil extracted from cypress wood contained $23.79 \%$ monoterpene, $76.07 \%$ sesquiterpene, and $0.13 \%$ other substances. The essential oil extracted from pine wood contained $81.49 \%$ monoterpene, $17.75 \%$ sesquiterpene, $0.55 \%$ diterpene, and $0.20 \%$ other substances. Further, the essential oil extracted from pine nut wood contained $67.90 \%$ monoterpene, $21.93 \%$ sesquiterpene $8.08 \%$ diterpene, and $2.09 \%$ other substances. Lastly, the essential oil extracted from Japanese larch contained
$34.82 \%$ monoterpene, $29.70 \%$ sesquiterpene, and $35.48 \%$ diterpene, indicating that their proportion is similar. The main substances in cypress included $\alpha$ -cadinol (19.25\%), $\tau$-muurolol $(14.20 \%), \alpha$-pinene (13.74\%), $\tau$-cadinol (9.84\%), $\delta$-cadinene $(7.37 \%)$, and $\gamma$-cadinene $(6.52 \%)$, whereas those in pine included $\alpha$ -pinene (47.16\%), longifolene (14.31\%), $\beta$-phellandrene (11.78\%), and $\beta$-pinene (11.02\%). The main substances in pine nut included $\alpha$-pinene (28.22\%), longifolene $(13.49 \%), \beta$-pinene $(10.79 \%)$, cembrene $(8.08 \%)$, and $\alpha$-terpineol $(7.63 \%)$, whereas those in Japanese larch included geranyl linalool (23.58\%), $\alpha$-pinene (18.57\%), $\alpha$-cadinol (6.24\%), and cembrene (6.12\%). Among the detected vaporizing substances, $\alpha$-pinene, $\beta$-pinene, limonene, fenchol, borneol, 4-terpineol, $\alpha$-terpineol, and $\delta$-cadinene were detected in all essential oils.

\subsection{Influence on $I L-4$ and $I L-13$ gene expression}

To determine the influence of essential oils extracted from the wood of the four coniferous tree species on the survival and reproduction of RBL-2H3 mast cells, these essential oils were processed at concentrations of $10^{-7} \%-10^{-5} \%$, and then MTT assay was performed. Cytotoxicity results are presented in Fig. 1.

When the essential oils were compared with the oils of the vehicle group (VE), cytotoxicity was not observed at concentrations of $10^{-7} \%-10^{-5} \%$. Accordingly, further evaluation confirmed the anti-inflammatory effect of all essential oils at a concentration of $10^{-7} \%$.

RBL-2H3 mast cells, derived from basophils, play crucial roles in anti-inflammatory activity together with other mast cells. They are known to be a useful model for the study of the effects of drugs triggering the release of IL-4 and IL-13, which cause inflammation by various external stimulation and regulate the immune system (Prussin and Metcalfe, 2003; Kindt et al., 2007). IL-4 and IL-13 released following mast cell activity 
Anti-Inflammatory Effect of Essential Oils Extracted from Wood of Four Coniferous Tree Species

Table 2. The major constituents of four coniferous oils

\begin{tabular}{|c|c|c|c|c|c|c|}
\hline \multirow{2}{*}{$\mathrm{RTa}$} & \multirow{2}{*}{ Compound } & \multirow{2}{*}{$\mathrm{KIb}$} & C. obtusa & P. densiflora & P. koraiensis & L. kaempferi \\
\hline & & & Area \% & Area \% & Area \% & Area \% \\
\hline 13.70 & Hexanal & 799 & & & 1.16 & \\
\hline 18.72 & 1-Hexanol & 858 & & & 0.41 & \\
\hline 27.02 & $\alpha$-Pinene & 928 & 13.74 & 47.16 & 28.22 & 18.57 \\
\hline 29.69 & Camphene & 943 & & 0.85 & 1.14 & 0.48 \\
\hline 30.35 & 2,4(10)-Thujadien & 947 & & 0.44 & & \\
\hline 34.95 & $\beta$-Pinene & 974 & 0.24 & 11.02 & 10.79 & 2.96 \\
\hline 37.56 & Myrcene & 953 & & 1.02 & & \\
\hline 40.46 & 3-Carene & 1011 & & & 3.32 & \\
\hline 42.31 & o-Cymene & 1032 & 0.15 & 0.53 & 1.55 & \\
\hline 42.80 & Limonene & 1037 & 0.75 & 1.52 & 4.01 & 2.62 \\
\hline 42.93 & $\beta$-Phellandrene & 1039 & 0.27 & 11.78 & & \\
\hline 43.07 & Eucalyptol & 1040 & & 0.13 & & \\
\hline 47.45 & Terpinolene & 1089 & & 0.36 & 0.38 & \\
\hline 47.72 & $\rho$-Cymenene & 1092 & & 0.17 & 0.59 & \\
\hline 48.70 & Nonanal & 1103 & & & 0.38 & \\
\hline 49.73 & Fenchol & 1117 & 0.45 & 0.36 & 1.02 & 0.60 \\
\hline 50.28 & $\alpha$-Campholenal & 1124 & & & 0.22 & \\
\hline 51.35 & Pinocarveol & 1138 & & 1.00 & 0.95 & \\
\hline 51.66 & Verbenol & 1142 & & 0.53 & & \\
\hline 51.82 & Camphor & 1145 & & & 0.28 & \\
\hline 52.44 & $\beta$-Terpineol & 1153 & & 0.11 & & \\
\hline 53.73 & Borneol & 1170 & 1.23 & 0.39 & 1.38 & 1.65 \\
\hline 54.10 & 3-Pinanone & 1175 & & 0.31 & 0.36 & \\
\hline 54.41 & 4-Terpineol & 1179 & 0.87 & 0.52 & 1.59 & 0.54 \\
\hline 54.83 & $\rho$-Cymenol & 1185 & 0.21 & 0.33 & 0.48 & \\
\hline 54.90 & Cryptone & 1186 & & 0.20 & & \\
\hline 55.57 & $\alpha$-Terpineol & 1195 & 3.28 & 2.12 & 7.63 & 4.67 \\
\hline 55.73 & Myrtenol & 1197 & & & 1.02 & 0.58 \\
\hline 56.72 & Verbenone & 1210 & & 0.85 & 0.47 & \\
\hline 58.20 & Citronellol & 1230 & 0.13 & & & \\
\hline 60.96 & 2-Decenal & 1267 & & & 0.31 & \\
\hline 61.22 & cis-Myrtanol & 1271 & & & & 1.61 \\
\hline 62.56 & Bornyl acetate & 1289 & 0.54 & & 1.26 & 0.56 \\
\hline 65.85 & $\alpha$-Terpinyl acetate & 1352 & 1.93 & & & \\
\hline 66.30 & $\alpha$-Longipinene & 1362 & & 0.44 & 1.33 & \\
\hline 66.59 & 2-Undecenal & 1368 & & & 0.36 & \\
\hline 67.39 & $\alpha$-Copaene & 1384 & 0.25 & & 1.38 & \\
\hline
\end{tabular}


Jiyoon YANG $\cdot$ Won-Sil CHOI $\cdot$ Jae-Woo KIM $\cdot$ Sung-Suk LEE $\cdot$ Mi-Jin PARK

\begin{tabular}{|c|c|c|c|c|c|c|}
\hline \multirow{2}{*}{$\mathrm{RTa}$} & \multirow{2}{*}{ Compound } & \multirow{2}{*}{$\mathrm{KIb}$} & C. obtusa & P. densiflora & P. koraiensis & L. kaempferi \\
\hline & & & Area \% & Area \% & Area \% & Area \% \\
\hline 67.46 & Longicyclene & 1386 & & 0.44 & & \\
\hline 67.92 & $\beta$-Elemene & 1395 & 1.17 & & & \\
\hline 68.17 & $(+)$-Sativene & 1401 & & 0.36 & 0.31 & \\
\hline 68.97 & Longifolene & 1423 & & 14.31 & 13.49 & \\
\hline 69.30 & $\beta$-Caryophyllene & 1432 & 0.22 & 0.56 & 1.31 & \\
\hline 70.20 & $\beta$-Farnesene & 1456 & & 0.17 & 0.29 & \\
\hline 70.64 & Humulene & 1468 & 0.46 & 0.11 & 0.29 & \\
\hline 70.77 & Ethyl cinnamate & 1472 & & & 0.71 & \\
\hline 71.23 & $\gamma$-Muurolene & 1485 & 2.79 & 0.14 & & 1.65 \\
\hline 71.53 & Germacrene-D & 1493 & & & & 0.75 \\
\hline 71.82 & $\beta$-Selinene & 1501 & 0.87 & & & 0.64 \\
\hline 72.01 & $\alpha$-Muurolene & 1507 & 4.16 & & 0.78 & 1.67 \\
\hline 72.20 & $\beta$-Bisabolene & 1514 & & & 0.36 & \\
\hline 72.53 & $\gamma$-Cadinene & 1525 & 6.52 & 0.11 & & 2.56 \\
\hline 72.65 & $\delta$-Cadinene & 1529 & 7.37 & 0.31 & 0.50 & 4.07 \\
\hline 72.78 & Calamenene & 1533 & 1.08 & & & 0.68 \\
\hline 73.25 & $\alpha$-Cadinene & 1549 & 0.78 & & & \\
\hline 73.42 & $\alpha$-Calacorene & 1554 & 0.43 & & & 0.70 \\
\hline 73.52 & 3,7(11)-Selinadiene & 1558 & & & & 0.58 \\
\hline 73.74 & Nerolidol & 1565 & 1.03 & & 0.52 & \\
\hline 74.72 & Gleenol & 1598 & 0.40 & & & \\
\hline 74.78 & $\gamma$-Eudesmol & 1600 & 0.28 & & 0.50 & \\
\hline 75.42 & Longiborneol & 1623 & & 0.52 & 0.43 & \\
\hline 75.61 & Carotol & 1630 & 1.21 & & & 0.99 \\
\hline 75.71 & Globulol & 1634 & 0.28 & & & \\
\hline 75.95 & Cubenol & 1642 & 2.14 & & 0.43 & 1.13 \\
\hline 76.30 & $\tau$-Cadinol & 1655 & 9.84 & & & 3.00 \\
\hline 76.36 & $\tau$-Muurolol & 1657 & 14.20 & 0.11 & & 3.66 \\
\hline 76.69 & $\alpha$-Cadinol & 1669 & 19.25 & 0.17 & & 6.24 \\
\hline 76.88 & Juniper camphor & 1676 & 1.08 & & & 0.79 \\
\hline 77.19 & Cadalene & 1688 & 0.22 & & & 0.60 \\
\hline 78.52 & Falcarinol & 1732 & 0.13 & & & \\
\hline 86.29 & Cembrene & 1956 & & 0.55 & 8.08 & 6.12 \\
\hline 88.24 & Manoyl oxide & 2024 & & & & 0.66 \\
\hline 88.38 & Atiserene & 2032 & & & & 0.52 \\
\hline 89.11 & Thunbergol & 2071 & & & & 4.61 \\
\hline 89.26 & Geranyl linalool & 2079 & & & & 23.58 \\
\hline
\end{tabular}

${ }^{\mathrm{a}} \mathrm{RT}$ : Retention time, ${ }^{\mathrm{b}} \mathrm{KI}:$ Kovats index on a DB-5 column with reference to $n$-alkanes $\left(\mathrm{C}_{9}-\mathrm{C}_{24}\right)$. 


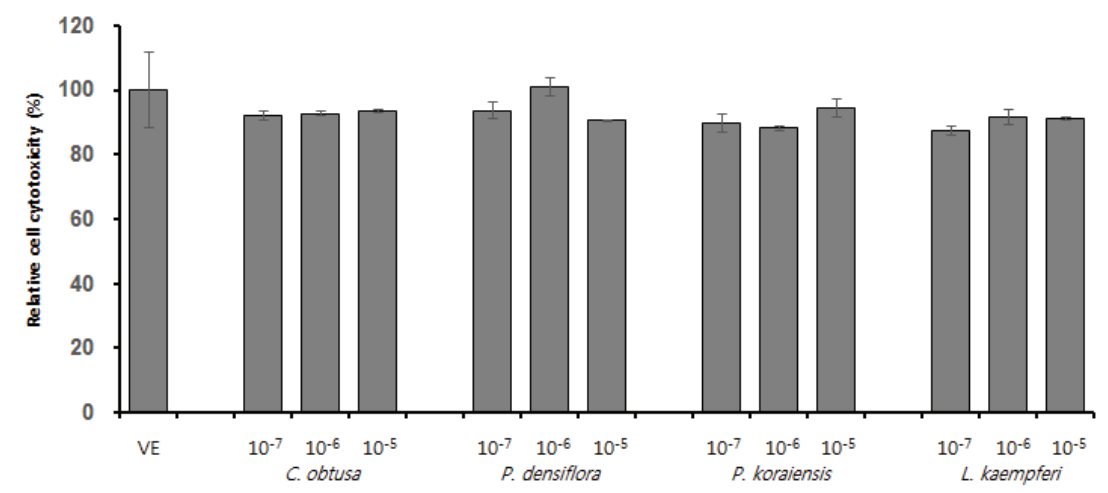

Fig. 1. Effects of four coniferous oils on the viability of RBL-2H3 cells. Group: VE(vehicle), treatment of $10^{-7} \sim 10^{-5} \%$ essential oil(C. obtusa, P. densiflora, P. koraiensis, L. kaempferi). Values are expressed as the mean \pm standard deviation.

increases Th2 reactions; and subsequently $\mathrm{Th} 2$ induces IgE production in $\mathrm{B}$ cells and thereby induces an allergic reaction. Because IL-13 shares its receptor with IL-4, it functions similar to IL-4; therefore, by examining the changes in their levels, anti-inflammatory effect can be investigated (Yoon and Pyo, 2012; Hershey et al., 1997).

The following groups were formed: VE, negative control (NC; group treated with LPS), positive control (PC; group treated with dexamethasone in LPS-induced RBL-2H3 mast cells), and treatment group (treatment with essential oils). The results of relative IL-4 and IL-13 gene expression were obtained based on the type of tree species.

As shown in Fig. 2(a), when LPS that induced an inflammatory reaction was incubated with RBL-2H3 mast cells, the relative gene expression of IL-4 increased by 6.6 times compared with that in VE. In PC, an inflammatory reaction was induced and the relative gene expression of IL-4 decreased by $82.8 \%$ compared with that in NC. In the treatment group, high antiinflammatory effects were observed. The relative gene expression of IL-4 decreased by $55.1 \%$ for essential oil extracted from cypress wood, $69.6 \%$ for pine, $63.2 \%$ for pine nut, and $45.8 \%$ for Japanese larch compared with that in NC.

As shown in Fig. 2(b) wherein the relative gene expression of IL-13 as the factor controlling inflammatory reaction is depicted, the relative gene expression of IL-13 increased by 5.2 times compared with that in VE when LPS was used. In contrast, after LPS-induced RBL-2H3 mast cells were exposed to dexamethasone and the essential oils, the relative gene expression of IL-13 decreased substantially. When these cells were exposed to dexamethasone, the relative gene expression of IL-13 decreased by $79.8 \%$. Compared with that in NC, the relative gene expression of IL-13 decreased by $51.1 \%$ for the essential oil extracted from cypress wood, $57.8 \%$ for pine, $57.1 \%$ for pine nut, and $34.5 \%$ for Japanese larch. Regarding all essential oils that inhibited the gene expressions of IL-4 and IL-13 in LPS-induced RBL-2H3 mast cells, allergic inflammation improved. All essential oils contain same substances including $\alpha$-pinene, limonene, and 4-terpineol, which have anti-inflammatory effect (Rufino et al., 2015). Therefore, the observed anti-inflammatory effects may be thought to be caused by these substances.

Cytokines activate proteins and are secreted in cells in the presence of immune or inflammatory reactions, and they are involved in transmission of information 
(a)

(b)
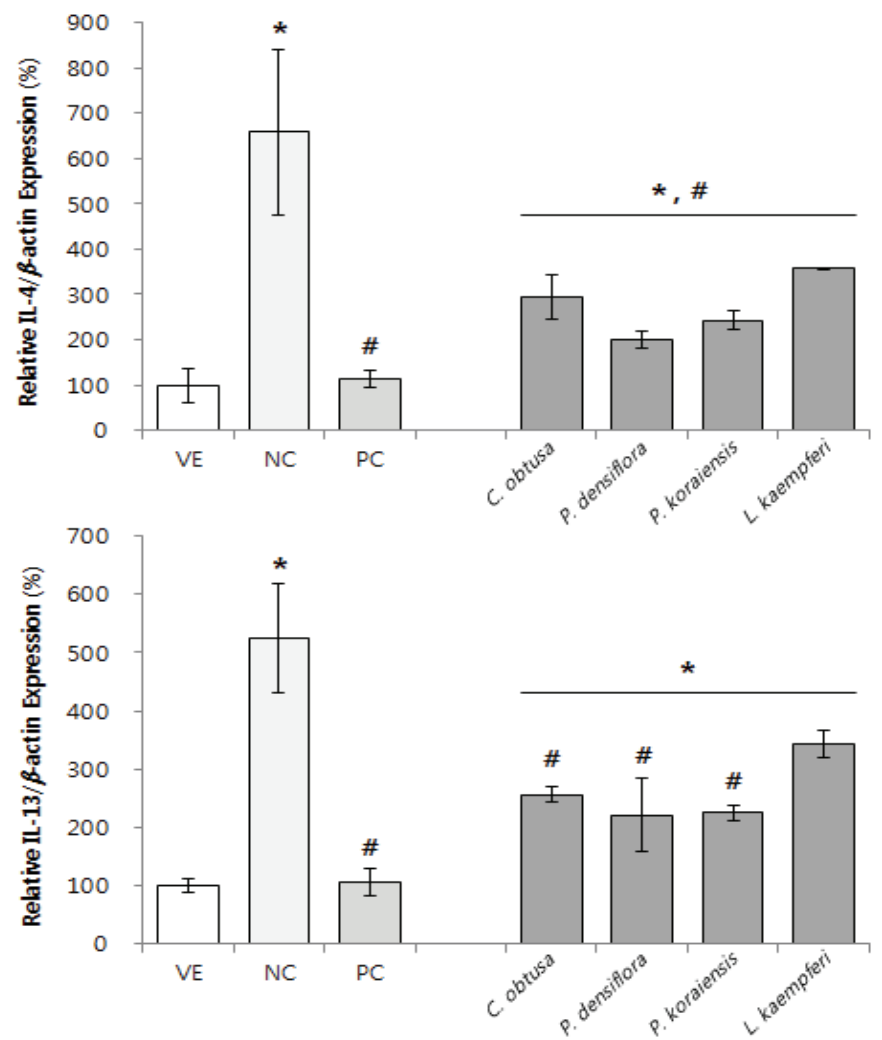

Fig. 2. Pro-inflammatory cytokine mRNA expression on RBL-2H3 cells treated with four coniferous oils. (a) mRNA expression level of IL-4, (b) mRNA expression level of IL-13. VE : vehicle, NC : negative control(group treated with lipopolysaccharide), PC : positive control(group treated with dexamethasone on lipopolysaccharideinduced RBL-2H3 cells), treatment of essential oil(C. obtusa, P. densiflora, P. koraiensis, L. kaempferi). Values are expressed as the mean \pm standard deviation. ${ }^{*} \mathrm{P}<0.05$ vs. $\mathrm{VE}\left(\right.$ vehicle); ${ }^{\#} \mathrm{P}<0.05$ vs. NC (lipopolysaccharidetreated group).

across cells. When an allergic reaction occurs, various cells are activated that trigger an inflammatory reaction via the release and import of chemical media. At this point, many types of cytokines participate directly or indirectly (Kwon and Song, 2012.). IL-4 is a controller of $\operatorname{IgE}$ (a mediator of an allergic reaction), and mast cells mediate immunity. Further, an increase in IL-4 levels is crucial for an allergic reaction (Iikura et al., 2001), and IL-13 functions as an important mediator of $\operatorname{IgE}$ production and maintenance (Howard et al., 2001). Because the relative gene expressions of IL-4 and IL-13 decreased following exposure to the essential oils extracted from pine and pine nut wood compared with that to other essential oils, Th2 cell activity was possibly inhibited and immunity was effectively regulated leading to the inhibition of $\mathrm{IgE}$ production. Its effectiveness in inhibiting the release of inflammatory mediators indicates its effectiveness in inhibiting type I allergic reactions. Moreover, the excellent anti-inflammatory effect of essential oils extracted from pine and pine nut wood compared with that of other essential oils 
is considered to have been caused by the differences in the substances present in these essential oils. In particular, $\beta$-pinene and longifolene are present in pine and pine nut at a high level compared with those in cypress and Japanese larch. $\beta$-Pinene was the highest in pine $(11.02 \%)$ followed by pine nut $(10.79 \%)$, Japanese larch $(2.96 \%)$, and cypress $(0.24 \%)$. The differences in these major substances are assumed to have caused the differences in the effectiveness of different tree species.

\subsection{Influence on $\beta$-hexosaminidase release}

The rate of $\beta$-hexosaminidase release, an index of exocytosis, was measured to assess the anti-inflammatory effects of the essential oils from the wood of the four coniferous tree species Fig. 3.

In VE, exocytosis was stimulated, leading to an increase in $\beta$-hexosaminidase release by 6.1 times compared with that in VE, and when dexamethasone (PC) was applied to LPS-induced mast cells, the release rate decreased by $77.9 \%$ compared with that in VE. Similar to that in PC, $\beta$-hexosaminidase release decreased in the group processed with the essential oils from the wood of the four coniferous tree species. When the essential oil extracted from cypress wood was used, the relative $\beta$-hexosaminidase release decreased by $38.1 \%$ compared with that in $\mathrm{NC}$, by $33.0 \%$ when essential oil extracted from pine wood was used, by $27.4 \%$ when essential oil extracted from pine nut was used, and by 9.1\% i essential oil extracted from Japanese larch was used. All essential oils inhibited $\beta$-hexosaminidase release in LPS-induced RBL-2H3 mast cells, suggesting that they have anti-inflammatory activity; this implies that the essential oils extracted from the wood of the four coniferous tree species inhibit exocytosis of RBL-2H3 mast cells caused by antigenic simulation, which differs according to the types of tree species.

$\beta$-Hexosaminidase is stored in secretory granules within mast cells. During immune activity, $\beta$-hexosaminidase is secreted with histamine and is used as the exocytosis marker for mast cells (Mastusa et al., 2002). Examinat-

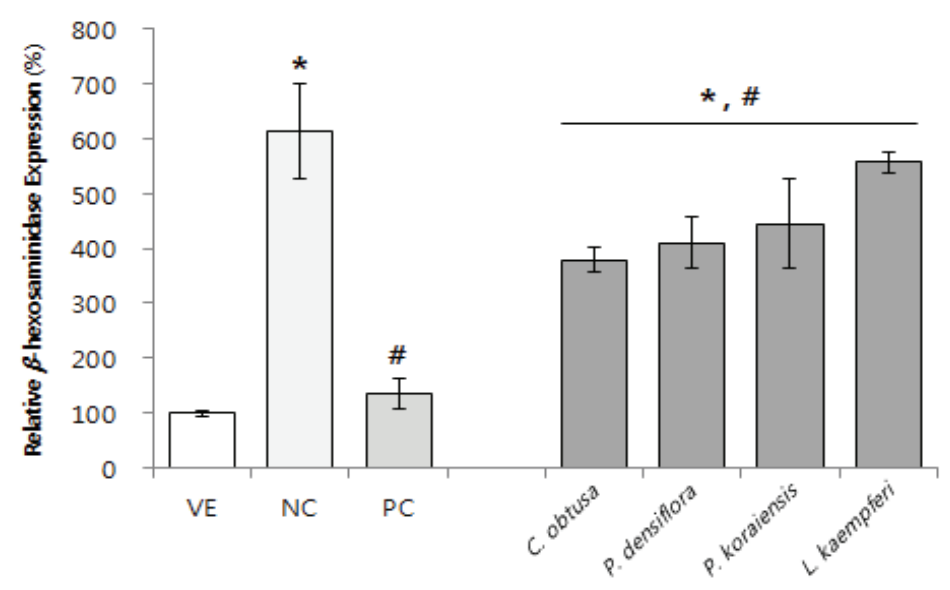

Fig. 3. Inhibitory effects of four coniferous oils on the release of $\beta$-hexosaminidase. VE : vehicle, NC : negative control(group treated with lipopolysaccharide), PC : positive control(group treated with dexamethasone on lipopolysaccharide-induced RBL-2H3 cells), treatment of essential oil(C. obtusa, P. densiflora, P. koraiensis, L. kaempferi). Values are expressed as the mean \pm standard deviation. ${ }^{*} \mathrm{P}<0.05$ vs. $\mathrm{VE}\left(\right.$ vehicle); ${ }^{*} \mathrm{P}<0.05$ vs. NC(lipopolysaccharide-treated group). 
ion of the effect of the essential oils that affect $\beta$ -hexosaminidase release, the essential oil extracted from cypress wood showed the highest inhibition rate, and the relatively high percentage of $\tau$-muurolol and $\alpha$ cadinol was remarkable. Given that RBL-2H3 mast cell exocytosis and the secretion of inflammatory mediators were effectively inhibited, $\tau$-muurolol and $\alpha$-cadinol are considered the mediators of type I allergic reactions. Moreover, IL-4 and IL-13 showed specific trends of gene expression, indicating that the essential oils extracted from the wood of pine and pine nut are effective in regulating inflammatory reaction by inhibiting Th2 cells. The essential oil extracted from cypress wood is the most effective in inhibiting inflammation-induced exocytosis. Such differences in the inhibitory effect according to the immunity pathway are considered because of the substances present in essential oils. Further studies are required to identify the bioactive substances responsible for anti-inflammatory effects.

\section{CONCLUSION}

In this study, bioactive substances and their effects on improving the anti-inflammatory effect of the essential oils extracted from the wood of cypress, pine, pine nut, and Japanese larch (the recommended tree species for timber designated by the Korea Forest Service) were studied.

The essential oils used in the experiments were extracted from grinded wood of the four coniferous tree species using hydrodistillation. Determination of their chemical composition using GC/MS revealed the prominent substances to be $\alpha$-pinene, $\beta$-pinene, fenchol, and $\alpha$-terpineol in all coniferous tree species, wherein each tree species showed different compositions of these major substances.

For the comparative analysis of the effects of bioactive substances on improving the anti-inflammatory effect of the essential oils extracted from the four coniferous tree species, inflammation was induced in RBL-2H3 mast cells by LPS and the essential oils were applied; then, inhibitory rates of exocytosis and $\beta$-hexosaminidase release were examined. Assessment of IL-4 and IL-13 gene expressions and $\beta$-hexosaminidase release rate in terms of inflammation, the relative IL- 4 and IL-13 gene expressions stimulated by LPS decreased substantially following the application of essential oils extracted from the wood of pine and pine nut, whereas the highest inhibition of $\beta$-hexosaminidase release was observed for cypress. Compared with other essential oils, those extracted from the wood of pine and pine nut contained higher percentages of $\beta$-pinene and longifolene, whereas those extracted from the wood of cypress contained higher percentages of $\tau$-muurolol and $\alpha$-cadinol, which is thought to be the cause of different degree of effectiveness according to the immunity pathway. Thus, further research on the bioactive substances responsible for the anti-inflammatory effect is warranted. Through this study, the essential oils extracted from the wood of the four coniferous tree species were found to be effective in improving allergic inflammation. The bioactive substances in essential oils are diffused in air when cypress, pine, pine nut and Japanese larch trees are used as wood materials for interior construction. Therefore, these trees applied as materials in interior renovations, could contribute to effectively improve allergic inflammation.

\section{REFERENCES}

Ahn, C., Park, M., Kim, J., Yang, J., Lee, S., Jeung, E. 2018. Cytotoxic evaluation of plant essential oils in human skin and lung cells. Journal of the Korean Wood Science and Technology 46(2): 166-177.

Carvalho-Freitas, M.I.R., Costa, M. 2002. Anxiolytic and sedative effects of extracts and essential oil from Citrus aurantium L. Biological and Pharmaceutical Bulletin 25(12): 1629-1633. 
Cho, E., Ju, S., Cho, H., Kim, M., Choi, I., Choi, Y. 2009. Inhibitory effects of ethanol extracts from pine buds (Pinus densiflora) on angiotensin converting enzyme, xanthine oxidase and nitric oxide synthesis. Journal of Life Science 19(11): 16291636.

Chon, S., Shin, M.Y. 1999. Effects of local climatic condition on the early growth in Korean white pine (Pinus koraiensis Sieb. et Zucc.) stands. Korean Journal of Agricultural and Forest Meteorology 1(1): 1-11.

Han, Y., Kim, M., Lee, H., Kang, J., Eom, C. 2017. Comparison of cellular anatomical, physical and mechanical properties between Dahurian larch and Japanese larch. Journal of the Korean Wood Science and Technology 45(5): 525-534.

Ham, Y., Kim, T. 2018. Plant extracts inhibiting biofilm formation by Streptococcus mutans without antibiotic activity. Journal of the Korean Wood Science and Technology 46(6): 692-702.

Hershey, G.K., FriedrichM, F.L., Esswein, A., Thomas, M.L., Chatila, T.A. 1997. The association of atopy with a gain-of-function mutation in the a subunit of the interleukin-4 receptor. The New England Journal of Medicine 337(24): 1720-1725.

Hong, E., Na., K., Choi, I., Choi, K., Jeung, E. 2004. Antibacterial and antifungal effects of essential oils from coniferous trees. Biological and Pharmaceutical Bulletin 27(6): 863-866.

Howard, T.D., Whittaker, P.A., Zaiman, A.I., Koppelman, G.H., Xu, J., Hanley, M.T., Meyer, D.A., Postma, D.S., Bleecker, E.R. 2001. Identification and association of polymorphisms in the interleukin-13 gene with asthma and atopy in a Dutch population. American Journal of Respiratory Cell and Molecular Biology 25(3): 377-384.

Iikura, M., Yamaguchi, M., Hirai, K., Miyamasu, M., Yamada, H., Nakajima, T. 2001. Regulation of surface FcepsilonRI expression on human eosinophils by IL-4 and IgE. International Archives of Allergy \& Immunology 124(4): 470-477.

Jeong, M., Yang, J., Choi, W., Kim, J., Kim, S.J., Park, M. Chemical compositions and antioxidant activities of essential oil extracted from Neolitsea aciculata (Blume) Koidz leaves. Journal of the Korean Wood Science and Technology 45(1): 96-106.

Kang, J., Son, Y., Yim, J., Jeon, J. 2016. Estimation of carbon stock and uptake for Larix Kaempferi Lamb.. Journal of Climate Change Research 7(4): 499-506.

Kim, I.H., Shin, M.Y., Kim, Y., Chon, S. 2001. Evaluation of reproductive growth in a mature stand of Korean Pine under stimulated climatic condition. Korean Journal of Agricultural and Forest Meteorology 3(4): 185-198.

Kim, S., Lee, S., Hong, C., Jang, S., Lee, S., Park, M., Choi, I. 2013. Evaluation on anti-dermatophyte effect of Larix (Kaempferi) essential oil on the morphological changes of Eermatophyte fungal hyphae. Journal of the Korean Wood Science and Technology 41(3): 247-257.

Kim, S., Lee, S., Cho, S., Hong, C., Park, M., Choi, I. 2016. Evaluation on anti-fungal activity and synergy effects of essential oil and their constituents from Abies holophylla. Journal of the Korean Wood Science and Technology 44(1): 113-123.

Kim, S., Lee, S., Cho, S., Hong, C., Park, S., Park, M., Choi, I. 2017. Antioxidant activities of Cryptomeria japonica leaves extracts by extraction methods. Journal of the Korean Wood Science and Technology 45(5): 495-510.

Kindt, T.J., Goldsby, R.A., Osborne, B.A., Kuby, J. 2007. Kuby Immunology (6th ed.), W.H. Freeman Publishers, New York, NY, USA.

Kong, W. 2004. Species composition and distribution of native Korean conifers. Journal of the Korean Geographical Society 39(4): 528-543.

Kwon, H., Song, C. 2012. Effect of Scutellaria barbata 
pharmacopuncture extract on degranulation and inflammatory mediator release in RBL-2H3 cells. Korean Journal of Acupuncture 29(3): 406-420.

Lee, M.., Park, S., Lee, S., Lee, H., Kil, D. 2014. Emission characteristics of volatile organic compounds by humidifier with using Hinoki cypress extracts. Journal of the Korean Wood Science and Technology 42(6): 747-757.

Li, Z., Chen, S., Yang, X., Wang, R., Min, H., Wu, L., Si, C., Bae, Y. 2018. Secondary metabolites with anti-complementary activity from the stem barks of Juglans mandshurica Maxim. Journal of the Korean Wood Science and Technology 46(2): 118-124.

Mastusa, H., Morikawa, T., Ueda, K., Managi, H., Yoshikawa, M. 2002. Structural requirements of flavonoids for inhibition of antigen-induced degranulation, TNF- $\alpha$ and IL-4 production from RBL-2H3 cells. Bioorganic \& Medicinal Chemistry 10(10): 3123-3128.

Min, H., Kim, Y., Bae, Y. 2017. Evaluation of biological activity on hawthorn tree (Crataegus pinnatifida) extracts. Journal of the Korean Wood Science and Technology 45(3): 317-326.

Prussin, C., Metcalfe, D.D. 2003. 4. IgE, mast cells, basophils, and eosinophils. Journal of Allergy and Clinical Immunology 111(2): S486-494.

Rho, J., Shin, E., Shin, S. 2014. Antifungal activities of essential oil from the roots of Angelica dahurica Bentham et Hooker f.. Yakhak Hoeji 58(1): 58-61. Rufino, A.T., Ribeiro, M., Judas, F., Salgueiro, L., Lopes, M.C., Cavaleiro, C., Mendes, A.F. 2014. Anti- inflammatory and chondroprotective activity of $(+)$ $\alpha$-pinene: structural and enantiomeric selectivity. Journal of Natural Products 77(2): 264-269.

Rufino, A.T., Ribeiro, M., Sousa, C., Judas, F., Salgueiro, L., Cavaleiro, C., Mendes, A.F. 2015. Evaluation of the anti-inflammatory, anti-catabolic and pro-anabolic effects of e-caryophyllene, myrcene and limonene in a cell model of osteoarthritis. European Journal of Pharmacology 750: 141-150.

Son, K., Song, J., Um, S., Paek, K.Y., Oh, H., Lee, J., Kim, J. 2001. Effect of absorption of essential oils on the changes of arousal and antistress. Horticulture Environment and Biotechnology 42(5): 614-620.

Tumen, I., Akkol, E.K., Süntar, I., Keles, H. 2011. Wound repair and anti-inflammatory potential of essential oils from cones of Pinaceae: preclinical experimental research in animal models. Journal of Ethnopharmacology 137(3): 1215-1220.

Yang, J., Ahn, C., Jeung, E., Choi, W., Kim, J., Park, M. 2017. Anti-inflammatory activity of essential oil extracted from Chamaecyparis obtusa (Sieb. et Zucc.) wood. Korean Journal of Pharmacognosy 48(1): 18-24.

Yun, M.S., Cho, H.M., Yeon, B.R., Choi, J.S., Kim, S.M. 2013. Herbicidal activities of essential oils from pine, pine nut, larch and khigan fir in Korea. Weed and Turfgrass Science 2(1): 30-37.

Yoon, S.J., Pyo, M.Y. 2012. Down-regulation of T helper 2-associated cytokine expression by fisetin. Yakhak Hoeji 56(5): 326-332. 


\title{
APPENDIX
}

\author{
(Korean Version)
}

\section{침엽수 4 종 목부 정유의 항염증 효과 평가}

초록 : 본 연구는 국내산 편백, 소나무, 잣나무, 일본잎갈나무 목부 정유의 항염증 효과를 평가 하였다. 실험에 사용된 정유는 각 수종의 목부에서 증류법(hydrodistillation)으로 추출되었다. 추출한 정유들을 GC-MS를 통해 성분 분석한 결과, 편백의 경우 $a$-cadinol (19.25\%), $\tau$-muurolol (14.20\%) 및 $a$-pinene (13.74\%)이, 소나무는 $a$-pinene (47.16\%), longifolene (14.31\%), $\beta$-phellandrene (11.78\%) 및 $\beta$-pinene (11.02\%)이 주요성분이었으며, 잣나무의 경우 $a$-pinene (13.49\%)와 longifolene (10.79\%), 낙엽송의 경우 geranyl linalool (23.58\%) 및 $\alpha$-pinene (18.57\%)이 주요성분으로 확인되었다. 침엽수 목부 정유들의 항염증 효과는 LPS(Lipopolysaccharide)로 염증반응이 유도된 RBL-2H3 비만세포주에 정유를 처리한 후 IL-4(interleukin-4), IL-13(interleukin-13), $\beta$-hexosaminidase의 발현 변화를 조사함으로써 평가하였다. MTT assay를 통한 세포 독성 평가 결과, 침엽수 4종 정유 모두 $10^{-7} \sim 10^{-5} \%$ 농도에서 세포 독성을 보이지 않았다. 염증반응이 유도된 RBL-2H3 세포에 침엽수 4종의 목부 정유를 $10 \%$ 농도로 처리하였을 때, LPS 처리군 대비 침엽수 4종의 목부 처리군에서 IL-4와 IL- 13 의 상대적 발현량이 큰 폭으로 감소하였으며, $\beta$-hexosaminidase 분비가 유의하게 억제되었다. 침엽수 정유 4종의 IL-4 상대적 발현량은 LPS 처리군 대비 소나무 $69.6 \%$, 잣나무 $63.2 \%$, 편백 $55.1 \%$ 그리고 낙엽송 $45.8 \%$ 감소하였다. IL- 13 의 상대적 발현량은 소나무 $57.8 \%$, 잣나무 $57.1 \%$, 편백 $51.1 \%$ 그리고 낙엽송 $34.5 \%$ 감소하였다. $\beta$-Hexosaminidase 분비의 경우 LPS 처리군 대비 편백 $38.1 \%$, 소나무 $33.0 \%$, 잣나무 $27.4 \%$ 그리고 낙엽송 9.1\% 억제하였다. Il-4, IL-13 및 $\beta$-hexosaminidase 분비를 비교한 결과, 침엽수 목부 정유 4종 중 소나무 정유의 활성이 가장 우수하였다. 이러한 결과는 국내 침엽수 4종의 목부 정유는 염증반응을 유발하는 싸이토카인의 발현 억제를 통하여 항염증 효과를 나타냄을 확인할 수 있었다.

\section{1. 서 론}

우리나라 국토 면적의 약 $64 \%(6,335,000 \mathrm{ha})$ 를 차지하는 산림 중 침엽수림은 약 $36.9 \%(2,339,000 \mathrm{ha})$ 로 약 $32.0 \%(2,029,000$ $\mathrm{ha}$ 를 차지하는 활엽수림보다 넓은 면적을 차지한다(Kong, 2004). 국내 임상별 임목축적량 또한 침엽수림이 $43.7 \%(403971300$ $\mathrm{m}^{3}, 172.7 \mathrm{~m}^{3} / \mathrm{ha}$ )로 많은 부분을 차지한다(산림청, 2016 산림기본통계). 침엽수 중에 편백, 소나무, 잣나무, 일본잎갈나무는 산림청이 지정한 용재수종으로 국내에 많이 식재되어 있다. 편백(Chamaecyparis obtusa Sieb. et Zucc.)은 1904년에 일본으로부 터 국내에 도입되어 남부지방의 경제수종으로 식재되고 있으며, 국토녹지사업으로 꾸준히 조림되고 있다(Lee et al., 2014). 편백의 목재는 재질이 우수하며 독특한 향을 지니고 있어 건축자재와 고급 가구재 등으로 많이 사용되고 있다. 편백 추출물에는 다양한 성분들이 함유되어 있으며, 여러 생리활성이 알려져 있다. 소나무(Pinus densiflora Sieb. et Zucc.)는 상록성 침엽수로서, 예로부터 잎, 솔방울, 송진 등 모든 부위가 이용되었으며, 그 외에 한방 또는 민간요법으로 신경통, 당뇨병, 고혈압 등의 성인병 치료에 이용되어 왔다(Cho et al., 2009). 우리나라의 여러 수종 중 소나무는 실생활과 밀접하게 연관되어 있으며, 문화적인 가치로서 가장 중요한 수종 중 하나로 인식되고 있다. 잣나무(Pinus koraiensis Sieb. et Zucc.)는 목재 이용 및 잣 종자를 식용으로 이용할 수 있어 이중적 가치를 가졌다. 내한성이 강하고 비교적 병충해에 저항력이 강하여, 1960년대 이후 장기 용재수종으로 식재가 장려된 주요 경제 수종 중 하나이다(Kim et al., 2001; Chon and Shin, 1999). 일본잎갈나무(Larix kaempferi Lamb.)는 1910년대에 일본으로부터 도입되어 우리나라 대부분의 지역에서 식재되고 있다. 일본잎갈나무는 성장 속도가 빨라 인공조림에 사용되며, 목재제품, 건축용 재료의 소재로 다양하게 활용되고 있다(Kang et al., 2016; Han et al., 2017). 산림에 대한 국민의 인식이 날로 증가하고 있으며, 그 효용가치에 대한 요구도 다양화되고 있는 실정이다. 소나무, 잣나무, 일본잎갈나무는 최근 국내에서 벌채량이 많은 수종이기도 하다. 이렇게 국내에 축적되어 있는 자원의 활용도를 높일 수 있는 방안과 벌채시 생산되는 부산물을 활용할 수 있는 연구들이 필요한 실정이다.

합성의약품 및 합성보존료의 위험성이 대두되면서 천연물질에 대한 관심이 증가하였고, 식물 정유를 포함한 수목의 추출물을 이용하여 항산화제(Jung et al., 2017; Kim et al., 2017), 항염증제(Min et al., 2017; Yang et al., 2017), 항진균제(Rho et al., 2014; Kim et al., 2013), 항보체제(Li et al., 2018) 및 바이오필름 생성 억제제(Ham and Kim, 2018) 등을 개발하기 위하여 다양한 연구가 이루어지고 있다. 식물의 이차대사물질인 정유는 다양한 생리활성을 보이며, 진정효과와 강장효과 등 
다양한 생리활성이 널리 알려져 있다. 특히 정유는 향기 요법에 사용되며, 인간의 몸과 마음의 균형을 회복시켜 인체 항상성 유지를 돕는다고 알려져 있다(Son et al., 2001). 이러한 특성은 정유 내 함유되어 있는 ketone, terpene, phenolic ether 등의 물질들에 의해 나타나는 것으로 보고되고 있다(Carvalho-Freitas and Costa, 2002). 침엽수종인 소나무, 잣나무, 편백, 전나무 등 잎으로부터 추출한 정유의 항균 효과를 연구한 결과도 있다(Hong et al., 2004; Kim et al., 2016). Ibrahim 등은 소나무과에 속하는 침엽수 6종의 cones에서 추출한 정유로 상처 치유와 항염증 효과를 평가하였다(Tumen et al., 2011). 동일한 과, 속 식물이지만 상처 치료와 항염증 활성의 효과 정도가 달랐다. 연구 결과에 의하면 Cedrus libani와 Abies cilicica subsp. cilicica가 항염증효과가 있음을 알아냈다. 또한 국내산 소나무, 잣나무, 일본잎갈나무, 분비나무 잎 정유의 제초활성이 연구되기도 하였다 (Yun et al., 2013). 4수종 정유의 기내 종자발아 제초활성 검정 결과, 소나무 잎 정유를 제외하고 제초활성을 보였다. 이러한 다양한 활성은 정유 내 성분과 농도에 따라 세포독성 및 세포 주기에 영향을 미치므로 적용 분야에 따른 수종 선택 및 농도 결정이 중요하다(Ahn et al., 2018).

이처럼 침엽수 정유의 다양한 생리활성 연구들이 이루어지고 있지만 이는 잎에 국한되어 있으며 목부 정유의 생리활성에 관한 연구는 부족한 실정이다. 본 연구는 국내 대표적인 용재수종인 편백(C. obtusa), 소나무(P. densiflora), 잣나무 $(P$. koraiensis), 일본잎갈나무(L. kaempferi) 4 종의 목부로부터 추출한 정유의 항염증 활성을 비교·평가하여 침엽수 목부의 효능을 구명하고자 하였다. 또한 이를 통해 침엽수 목부 정유가 알러지성 질환을 예방하거나 개선할 수 있는 물질로 활용이 가능한지를 확인하고자 하였다.

\section{2. 재료 및 방법}

\section{1. 공시재료}

공시재료로는 편백, 소나무, 잣나무, 낙엽송 목부를 사용하였다. 편백(Chamaecyparis obtusa Sieb. et Zucc.)과 소나무(Pinus densiflora Sieb. et Zucc.)는 남해에서 2014년 12월에 벌채된 것으로 가평 산림조합을 통해서 구입하였다. 낙엽송(Larix kaempferi Sieb. et Zucc.)는 2015년 12월 평창에서, 잣나무(Pinus koraiensis Sieb. et Zucc.)는 2016년 1월에 가평에서 벌채된 목부를 구입하였다.

\section{2. 정유 추출 및 수율 분석}

편백, 소나무, 잣나무, 낙엽송의 목부를 분쇄하여 증류법(hydrodistillation)으로 정유를 추출하였다. $10 \mathrm{~L}$ 둥근바닥 플라스크 에 약 $1 \mathrm{~kg}$ 시료를 넣고 $6 \mathrm{~L}$ 증류수를 부은 후 $105^{\circ} \mathrm{C}$ 로 가열하여 휘발되는 성분을 냉각시켜 정유를 얻었다. 더 이상 정유가 늘어나지 않을 때까지 추출하였으며, 약 7시간 동안 추출하였다. 추출된 정유는 무수 $\mathrm{Na}_{2} \mathrm{SO}_{4}(\mathrm{SAMCHUN}, 98.5 \%)$ 로 수분을 제거한 후 실험에 사용될 때까지 냉장보관하였다.

정유수율은 다음 식에 의해 계산되었다.

$$
\text { 수율 }(\%(\mathrm{w} / \mathrm{w}))=\frac{\text { 추출정유의무게 }(g)}{\text { 시료의 전건무게 }(g)} \times 100 \%
$$

\section{3. 세포배양}

침엽수 4종 목부 정유의 항염증 효과를 알아보기 위해 RBL-2H3 비만세포(CRL-22256 ${ }^{\mathrm{TM}}$; American Type Culture Collection, Manassas, VA, USA)를 분양 받아 본 연구에 사용하였다. $\mathrm{RBL}-2 \mathrm{H} 3$ 세포는 $37^{\circ} \mathrm{C}, 5 \% \mathrm{CO}_{2}$ 조건의 배양기 (Panasonic, MCO-19AIC)에서 10\% FBS(fetal bovine serum; Gibco), $1 \%$ penicillin-streptomycin(Gibco)와 $0.4 \mu \mathrm{L} / \mathrm{mL}$ mycroplasma guard가 포함된 DMEM(dubecco's modified eagle medium; Gibco)배지로 배양하였다.

\section{4. 정유의 성분 분석}

GC-MS(Trace 1310/ISQ-LT, ThermoScientific, USA)를 이용하여 침엽수 4종의 목부 정유를 정성분석 하였으며, 분석조건 은 다음과 같다.

Tr-5MS capillary column(30 m x $0.25 \mathrm{~mm} \times 0.25 \mu \mathrm{m}$; Thermoscientific, USA)을 사용하였으며 carrier gas는 헬륨(1 $\mathrm{mL} / \mathrm{min}, 25 \mathrm{psi})$ 을 사용하고, 시료 주입구는 $250^{\circ} \mathrm{C}$ 로 유지하였다. 오븐은 $40^{\circ} \mathrm{C}$ 에서 3 분간 유지하고 $3^{\circ} \mathrm{C}$ 씩 승온하여 $200^{\circ} \mathrm{C}$ 까지 올린 뒤, $15^{\circ} \mathrm{C}$ 씩 승온하여 $340^{\circ} \mathrm{C}$ 까지 올리고 10 분간 유지하였다. 검출된 화합물은 $\mathrm{FID}$ 신호와 질량스펙트럼 모두를 기록하였 다. $\mathrm{FID}$ 는 $280^{\circ} \mathrm{C}$ 조건하에 make-up 가스는 헬륨으로 $40 \mathrm{~mL} / \mathrm{min}$ 을 유지하였다. 질량분석기의 인터페이스와 이온소스의 
Anti-Inflammatory Effect of Essential Oils Extracted from Wood of Four Coniferous Tree Species

온도는 각각 $280^{\circ} \mathrm{C}$ 와 $250^{\circ} \mathrm{C}$ 로 유지하였고, 질량스펙트럼은 $\mathrm{EI}-$ 스캔 범위 $35 \sim 360 \mathrm{~m} / \mathrm{z}$ 로 $0.2 \mathrm{scans} / \mathrm{s}$ 의 속도로 획득하였다. 분석한 정유 내 물질들은 시료의 TIC(total-ion chromatogram)에서 $\mathrm{S} / \mathrm{N}$ 비율이 100 이상인 피크들의 질량스펙트럼을 NIST 11(National Institute of Standards and Technology, USA) mass spectral library와 비교하여 match 값이 가장 높은 것을 선택하 였다. 또한 정유 성분 확인을 위해 $n$-alkanes $\left(\mathrm{C}_{8} \sim \mathrm{C}_{20}\right.$, Sigma-Aldrich)을 이용하여 $\mathrm{KI}($ Kovats retention index)를 구하였다.

\subsection{MTT assay}

RBL-2H3 비만세포에 대한 정유의 세포독성을 평가하기 위해 MTT(3-(4, 5-dimethylthiazole-2-yl)-2, 5-diphenyl-tetrazolium bromide) assay를 수행하였다.

96-well plate의 각 well에 $200 \mu \mathrm{L}$ 의 배지와 $8 \times 10^{3}$ cells/well을 분주하고 $37^{\circ} \mathrm{C}, 5 \% \mathrm{CO}_{2}$ 조건의 인큐베이터에서 하루 동안 배양시켰다. $10^{-7} \sim 10^{-5} \%$ 농도의 침엽수 4종의 목부 정유를 처리한 비만세포에 MTT reagent(Sigma, Cat.\#. 11465007001)를 첨가한 후, $37^{\circ} \mathrm{C}$ 인큐베이터에서 6시간 동안 방치하였다. 성장배지와 MTT reagent를 제거한 후, DPBS(dulbecco's phosphate-buffered saline; Gibco)로 세척하였다. 각 well에 $100 \mu \mathrm{L} \mathrm{DMSO(dimethyl} \mathrm{sulfoxide;} \mathrm{Sigma)를} \mathrm{첨가한} \mathrm{후,} \mathrm{상온에서}$ 10 분간 보관하였다.

Spectrophotometer로 $540 \mathrm{~nm}$ 파장에서 농도별 침엽수 4종의 목부 정유를 처리한 세포의 흡광도를 측정하였다.

\subsection{Real-time PCR에 의한 $\mathrm{mRNA}$ 정량분석}

$\mathrm{RBL}-2 \mathrm{H} 3$ 세포를 $3 \times 10^{5}$ cell/well 농도로 6 well plate에 분주하여 24시간 배양한 후 $1 \mu \mathrm{g} / \mathrm{mL}$ LPS(lipopolysaccharide)와 침엽수 4종의 목부 정유를 처리하였다. 24시간 배양 후 6-well plate의 각 well에 배양된 세포에 $500 \mu \mathrm{L} \mathrm{TRIzol}$ reagent(Invitrogen, Life Technologies)을 첨가하여 세포를 용해한 후 tube에 옮긴 후, $100 \mu \mathrm{L}$ chloroform을 첨가하여 14,000 $\mathrm{rpm}$ 에서 10 분간 원심분리하였다. 상층액 $150 \mu \mathrm{L}$ 를 분취한 후 동량의 isopropanol을 첨가한 뒤, $-20^{\circ} \mathrm{C}$ 에서 24 시간동안 $\mathrm{RNA}$ 를 응축시켰다. $4^{\circ} \mathrm{C}, 14,000 \mathrm{rpm}$ 으로 10 분 동안 원심분리한 뒤 상층액을 제거하고, $200 \mu \mathrm{L} \mathrm{DEPC-EtOH}$ 을 첨가하여 한차례 원심분리를 실시한 후 상층액을 완전 제거하였다. $20 \mu \mathrm{L} \mathrm{DEPC-DW}$ 를 첨가하여 $55^{\circ} \mathrm{C}$ 에서 5 분 동안 가온한 뒤 RNA 농도를 측정하였다. RNA 농도는 micro-plate spectrophotometer(Epoch, model Take 3; BioTek Inc., winooski, VT, USA)를 이용하여 $260 \mathrm{~nm}$ 에서 측정하였다. 정량분석을 통해 mRNA로부터 cDNA를 합성한 후 7300 Real-time PCR System(Applied Biosystems, Foster, CA, USA)기기를 이용하여 Real-Time PCR을 수행하였다. Oligonucleotide primer의 sequences를 Table 1 에 나타내었다. 각 목부 정유 처리군들의 상대적 발현량 값은 RQ software(version 1.3, Applied Biosystems)를 이용하여 분석하였다.

\section{7. $\beta$-Hexosaminidase 분비량 분석}

염증반응이 유도된 RBL-2H3 비만세포에서 침엽수 4종의 목부 정유에 의한 $\beta$-hexosaminidase의 분비량 변화를 분석하기 위하여 96-well plate에 well당 $8 \times 10^{3}$ cells을 분배한 후 DNP-specific $\operatorname{IgE}(800 \mathrm{ng} / \mathrm{mL}, \mathrm{Sigma}$, 미국)로 자극하였다. 배지 제거 후 Tyrodes' assay buffer[119 mM NaCl, $4.74 \mathrm{mM} \mathrm{KCl}, 2.5 \mathrm{mM} \mathrm{CaCl}, 1.19 \mathrm{mM} \mathrm{MgSO}, 10 \mathrm{mM}$ HEPES, $5 \mathrm{mM}$ glucose, $0.1 \%(\mathrm{w} / \mathrm{v}) \mathrm{BSA}, \mathrm{pH} 7.3]$ 로 2 회 세척 후 15 분 배양하였으며, 침엽수 4 종의 목부 정유와 DNP-BSA를 1 시간 처리하였 다. 그 후 상층액 $50 \mu \mathrm{L}$ 를 tube에 옮기고 $200 \mu \mathrm{L}$ 의 $1 \mathrm{mM}$ P-nitrophenyl-N-acetyl- $\beta$-D-glucosaminide와 혼합한 뒤 $37^{\circ} \mathrm{C}$ 에서 1 시간 배양하였다. 반응 종결을 위하여 $0.05 \mathrm{M}$ sodium bicarbonate buffer를 넣어준 후 $405 \mathrm{~nm}$ 파장에서 흡광도를 측정하였다.

\section{3. 결과 및 고찰}

\section{1 정유의 수율 및 성분}

침엽수 4종의 목부로부터 hydrodistillation 방법으로 추출한 정유의 수율을 계산하였다. 편백 목부 정유는 $0.86 \%$ 의 수율을 보였으며, 소나무 목부 정유는 $0.75 \%$ 의 수율을 보였다. 잣나무 목부 정유의 수율이 $0.25 \%$, 낙엽송 목부 정유의 수율이 $0.06 \%$ 을 보인 것과 비교하면 상당히 높은 수율을 보였다.

GC-MS 분석을 통해 확인된 침엽수 4종 목부 정유의 성분들은 Table 2에 나타내었다.

편백 목부 정유 내 monoterpene $23.79 \%$, sesquiterpene $76.07 \%$, 그 외 성분이 $0.13 \%$ 를 차지하였다. 소나무 목부 정유는 monoterpene $81.49 \%$, sesquiterpene $17.75 \%$, diterpene $0.55 \%$, 그 외 성분 $0.20 \%$ 로 구성되었다. 잣나무 목부 정유는 monoterpene $67.90 \%$, sesquiterpene $21.93 \%$, diterpene $8.08 \%$, 그 외 성분이 $2.09 \%$ 이었으며, 일본잎갈나무 목부 정유는 
monoterpene $34.82 \%$, sesquiterpene $29.70 \%$, diterpene $35.48 \%$ 비율로 구성되어있다. 소나무와 잣나무의 목부 정유는 monoterpene의 성분 비율이 높은 반면, 편백 목부 정유는 sesquiterpene의 비율이 높은 차이를 보였다. 일본잎갈나무 목부 정유의 경우 monoterpene, sesquiterpene 및 diterpene 성분이 차지하는 비율이 비슷한 특징을 보였다. 편백의 주요성분은 $19.25 \%$-cadinol, $14.20 \%$-muurolol, $13.74 \%$-pinene, 9.84\% $\tau$-cadinol, $7.37 \% \delta$-cadinene, $6.52 \% \gamma$-cadinene이, 소나무는 $47.16 \%$ a-pinene, $14.31 \%$ longifolene, $11.78 \% \beta$-phellandrene, $11.02 \% \beta$-pinene이 확인되었다. 잣나무의 경우 $28.22 \% a$ -pinene, $13.49 \%$ longifolene, $10.79 \% \beta$-pinene, $8.08 \%$ cembrene, $7.63 \%$-terpineol등이 주요성분이었으며, 일본잎갈나무 목부 정유의 주요성분은 $23.58 \%$ geranyl linalool, $18.57 \%$ a-pinene, $6.24 \%$ a-cadinol, $6.12 \%$ cembrene으로 확인되었다.

검출된 휘발성 성분들 중 $a$-pinene, $\beta$-pinene, limonene, fenchol, borneol, 4-terpineol, $a$-terpineol, $\delta$-cadinene이 침엽수 4종의 목부 정유에서 공통적으로 검출되었다.

\section{2. $\mathrm{IL}-4$ 와 $\mathrm{IL}-13$ 유전자 발현에 미치는 영향}

편백, 소나무, 잣나무, 낙엽송 목부 정유가 RBL-2H3 세포 생존 및 증식에 미치는 영향을 알아보고자 $10^{-7} \sim 10^{-5} \%$ 농도로 정유를 처리하여 MTT assay를 실행하였다. 세포 독성평가 결과는 Fig. 1과 같다.

침엽수 4종의 목부 정유들은 정상군과 비교하였을 때 $10^{-7} \sim 10^{-5} \%$ 농도에서 세포 독성을 보이지 않는 것을 확인하였다. 이러한 결과를 바탕으로 침엽수 4 종 목부 정유의 항염증 효과를 확인하기 위한 정유의 처리농도를 $10^{-7} \%$ 농도로 결정하였다.

호염구인 RBL-2H3 세포는 비만세포와 함께 알러지성 염증 반응에서 가장 핵심적인 역할을 한다. 다양한 외부자극에 의해 염증을 유발하고 면역을 조절하여 IL-4 및 IL-13 분비에 관여하는 약물들의 효과 연구에 좋은 모델로 알려져 있다(Prussin and Metcalfe, 2003; Kindt et al., 2007). 비만세포 활성화를 통해 분비되는 IL-4와 IL-13 등은 Th2 세포의 반응을 증가시키고, Th2는 이어서 B세포의 IgE 생성을 유도하여 알레르기성 반응을 일으킨다. IL-13은 IL-4와 수용체를 공유하여 IL-4와 유사한 작용을 하므로 두 싸이토카인의 변화를 조사하여 알러지성 염증반응 효과를 조사할 수 있다(Yoon and Pyo, 2012; Hershey et al., 1997).

침엽수 4종의 목부 정유가 알러지성 염증반응에 미치는 영향을 알아보기 위해 염증반응이 유도된 RBL-2H3 세포에 목부 정유들을 처리한 후 $\mathrm{IL}-4, \mathrm{IL}-13$ 의 발현 변화를 조사하였다. 정상군(VE)과 비만세포 내 염증반응을 유도하는 LPS 처리군(NC), 염증 유발 후 스테로이드성 항염증제로 알려진 dexamethasone 처리군(PC)과 침엽수 4종의 목부 정유 처리군(C. obtusa, P. densiflora, P. koraiensis, L. kaempferi)으로 나누어 진행하였다. 수종별 IL-4와 IL-13 유전자의 상대적 발현량을 조사한 결과는 Fig. 2에 나타내었다.

Fig. 2-(a)에 나타난 것처럼 비만세포에 염증반응을 유도하는 LPS를 처리하자 정상군(VE)에 비해 IL-4의 상대적 발현량이 약 6.6배 증가하였다. 염증반응이 유도된 비만세포에 염증치료제인 dexamethasone을 처리하자 IL-4의 상대적 발현량이 염증 유발군(NC) 대비 약 $82.8 \%$ 감소하였다. 침엽수 4종의 목부 정유 처리군에서도 높은 항염증 효과를 보였다. 편백 목부 정유 처리군의 IL-4 발현량은 염증유발군(NC) 대비 약 $55.1 \%$ 감소하였으며, 소나무 목부 정유 처리군은 약 $69.6 \%$, 잣나무 목부 정유 처리군에서는 약 $63.2 \%$, 낙엽송 목부 정유 처리군은 약 $45.8 \%$ 감소하였다.

염증반응 조절인자인 IL-13의 상대적 발현량을 비교한 Fig. 2-(b)를 보면 염증 유발인자인 LPS를 처리하자 IL-13 상대적 발현량이 정상군(VE)에 비해 약 5.2배 증가하였다. 이와 대조적으로 RBL-2H3에 염증을 유발한 후 항염증제인 dexamethasone 과 침엽수 4종의 목부 정유를 처리하자 IL-13의 상대적 발현량이 큰 폭으로 감소하였다. 염증반응이 유도된 비만세포에 dexamethasone을 처리하자 IL-13의 상대적 발현량이 약 $79.8 \%$ 감소하였다. 편백 목부 정유 처리시 IL- 13 의 상대적 발현량은 염증유발군(NC) 대비 약 $51.1 \%$ 감소하였으며, 소나무 목부 정유 처리군은 약 $57.8 \%$, 잣나무 목부 정유 처리군에서는 약 $57.1 \%$, 낙엽송 목부 정유 처리군은 약 $34.5 \%$ 감소하였다. 침엽수 4종의 목부 정유가 염증반응이 유도된 비만세포 내 IL-4와 IL-13의 발현을 억제함으로써 알러지성 염증개선효과를 보였다. 4종 정유에는 공통적으로 a-pinene, limonene 및 4-terpineol 성분들이 함유되어 있는데, 이 성분들은 항염증 효과가 있는 것으로 보고되어 있다(Rufino et al., 2015). 따라서 이러한 성분들에 의해 항염증 효과가 나타나는 것으로 사료된다.

싸이토카인이란 면역반응이나 염증반응이 일어날 때 세포에서 분비되는 단백활성물질로, 세포간의 정보전달에 관여한다. 알레르기 반응이 일어나면 여러 종류의 세포들이 활성화되어 화학적 매개물질들의 분비 및 유입으로 염증 반응을 일으키며, 이때 여러 종류의 싸이토카인이 직·간접적으로 관여한다(Kwon and Song, 2012.). IL-4는 제 I 형 알레르기 반응의 매개체인 $\mathrm{IgE}$ 와 비만세포 매개성 면역반응의 조절자로 IL-4의 증가는 알레르기 발생에 중추적인 것으로 알려져 있으며(Iikura et al., 2001), IL-13은 IgE 생산과 유지에 중요한 매개체로 작용한다(Howard et al., 2001). 염증반응에 있어 다른 수종대비 소나무와 잣나무 목부 정유가 IL-4와 IL-13 상대적 발현량을 감소시킨 것을 보아 Th2 세포의 활성을 억제시키고, 면역반응을 효과적으 로 조절하여 $\mathrm{IgE}$ 의 생성을 억제하였을 것으로 판단된다. 염증매개물질의 분비를 효과적으로 억제하는 것을 보아 제 I 형 
Anti-Inflammatory Effect of Essential Oils Extracted from Wood of Four Coniferous Tree Species

알레르기 반응을 유의하게 억제하는 효과가 있는 것으로 보인다. 또한 다른 정유에 비해 소나무와 잣나무 정유가 항염증 효과가 우수한 것은 정유에 함유되어 있는 성분의 차이에서 기인한 것으로 보인다. 특히 $\beta$-pinene과 longifolene은 편백과 낙엽송에 비해 소나무와 잣나무에서 높은 비울로 함유되어 있다. $\beta$-Pinene는 편백 $0.24 \%$, 낙엽송 $2.96 \%$ 에 비해 소나무 $11.02 \%$, 잣나무 $10.79 \%$ 으로 높은 비율을 차지하였으며, longifolene은 소나무와 잣나무에만 각 $14.31 \%, 13.49 \%$ 로 큰 비중을 차지하였다. 이러한 주요 성분들의 차이가 효능의 차이를 나타내는 것으로 추정된다.

\section{3. $\beta$-Hexosaminidase 분비에 미치는 영향}

침엽수 4종 목부 정유의 알러지성 염증반응 개선 효과를 평가하기 위해 탈과립의 지표인 $\beta$-hexosaminidase의 분비량을 측정하였다. 그 결과는 Fig. 3과 같다.

염증 유발인자인 LPS를 처리한 대조군은 탈과립이 촉진되어 $\beta$-hexosaminidase 분비가 정상군(VE)에 비해 약 6.1배 증가하 였고, 염증반응이 유도된 RBL-2H3에 dexamethasone(PC)을 처리하였을 때 분비량이 LPS 처리군 대비 약 $77.9 \%$ 감소하였다. 침엽수 4종의 처리군도 dexamethasone과 마찬가지로 $\beta$-hexosaminidase 분비가 감소하였다. 편백 목부 정유 처리시 $\beta$ -hexosaminidase의 상대적 분비량은 염증유발군(NC) 대비 약 $38.1 \%$ 감소하였으며, 소나무 목부 정유 처리군은 약 $33.0 \%$, 잣나무 목부 정유 처리군에서는 약 $27.4 \%$, 낙엽송 목부 정유 처리군은 약 $9.1 \%$ 감소하였다. 침엽수 4 수종의 정유 모두 염증반응이 유도된 비만세포의 $\beta$-hexosaminidase 분비를 억제하였으며, 항염증 활성을 보이는 것을 확인하였다. 이는 침엽수 4수종의 목부 정유가 항원 자극에 의한 비만세포의 탈과립을 억제하여 항염증 효과를 나타낸다고 볼 수 있으며, 수종마다 차이가 있음을 알 수 있다.

$\beta$-Hexosaminidase는 비만세포 내 분비과립에 저장되어 있다가 비만세포가 면역학적으로 활성화될 때 histamine과 함께 분비되어 비만세포 탈과립의 표지인자로 사용된다(Mastusa et al., 2002). $\beta$-Hexosaminidase 분비에 미치는 침엽수 4 종 목부 정유의 효과를 살펴본 결과, 편백 목부 정유 처리군에서 가장 높은 억제효과를 보였으며, $\tau$-muurolol과 $\alpha$-cadinol이 비중이 타 수종에 비해 높은 점에 주목하였다. RBL-2H3 세포 탈과립과 염증매개물질의 분비를 효과적으로 억제하는 것으로 보아 제 I 형 알레르기 반응을 유의하게 억제하는 효과물질이 $\tau$-muurolol과 $a$-cadinol로 판단된다. 또한 IL-4와 IL-13 유전자 발현 변화를 조사한 결과와 다른 경향성을 보이는 것을 보아 소나무와 잣나무 목부 정유는 $\mathrm{Th} 2$ 세포의 억제를 통해 염증 반응을 조절하는데 효과적이며, 편백 목부 정유는 염증 반응에 의한 탈과립을 억제하는데 가장 효과적이라 판단된다. 이러한 면역반응 pathway별 다른 억제효과는 수종 내 정유 성분에 의한 것으로 사료되며 추후 각 수종의 목부 정유 성분 중 항염증 효과를 보이는 활성성분을 구명할 필요가 있다.

\section{4. 결 론}

본 연구에서는 국내 침엽수 4종의 목부 정유 효과를 구명하고자 산림청이 지정한 용재수종이며 조림 권장 수종인 편백, 소나무, 잣나무, 낙엽송 목부 정유의 성분 분석 및 알러지성 염증 개선효과를 비교분석하였다.

실험에 사용된 정유는 증류법(hydrodistillation)으로 편백, 소나무, 잣나무, 낙엽송 목부를 분쇄하여 정유를 추출하였다. 추출 한 목부 정유들을 GC-MS를 통해 성분 분석한 결과, 항염증 효과 물질로 알려진 $a$-pinene, $\beta$-pinene, fenchol 및 $\alpha$-terpineol 등이 침엽수 4종의 목부 정유에서 공통적으로 검출되었으며, 수종마다 주요성분에 차이를 보였다. 침엽수 4종 목부 정유의 염증 개선효과를 비교분석하고자 비만세포주 RBL-2H3에 LPS로 염증을 유발한 후 정유를 처리하여 세포 탈과립과 염증매개물 질 분비 억제효과를 조사하였다. 염증 관련 싸이토카인인 IL-4 및 IL-13의 발현과 $\beta$-hexosaminidase의 분비량을 측정한 결과, LPS에 의해 자극된 IL-4와 IL-13의 상대적 발현량이 소나무와 잣나무 목부 처리군에서 큰 폭으로 감소하였으며, $\beta$ -hexosaminidase의 분비를 편백 목부 정유가 가장 효과적으로 억제하였다. 타 수종대비 소나무와 잣나무 목부 정유에서 $\beta$-pinene 과 longifolene이 큰 비중을 차지하고, 편백 목부 정유에서 $\tau$-muurolol과 $a$-cadinol의 비중이 높은 점이 면역반응의 pathway에 따라 서로 다른 효과의 정도를 보이게 하는 원인이라 판단된다. 따라서 추후 소나무와 잣나무 목부 정유 성분 중 항염증 효과를 보이는 활성성분을 구명할 필요가 있다.

본 연구를 통해 침엽수 4종의 목부 정유는 효과 정도의 차이는 있지만 알러지성 염증을 개선하고 효과가 있음을 확인할 수 있었다. 목재에 함유되어 있는 정유 성분들은 편백, 소나무, 잣나무 및 일본잎갈나무 등이 건축재나 인테리어재로 사용될 때 공기 중으로 목재에서 방산되는 물질들이다. 따라서 목재로 실내 환경에 적용했을 경우에 알러지성 염증을 개선하는데 영향을 줄 수 있을 것으로 사료된다. 